Original article

\title{
A contemporary series of renal masses with emphasis on recently recognized entities and tumors of low malignant potential: A report based on 624 consecutive tumors from a single tertiary center
}

\author{
Maria Rosaria Raspollini ${ }^{\mathrm{a}, *}$, Ilaria Montagnani ${ }^{\mathrm{a}}$, Rodolfo Montironi ${ }^{\mathrm{b}}$, Liang Cheng ${ }^{\mathrm{c}}$, \\ Guido Martignoni ${ }^{\mathrm{d}}$, Andrea Minervini ${ }^{\mathrm{e}}$, Sergio Serni ${ }^{\mathrm{e}}$, Giulio Nicita ${ }^{\mathrm{e}}$, Marco Carini ${ }^{\mathrm{e}}$, \\ Antonio Lopez-Beltran ${ }^{\mathrm{f}}$ \\ ${ }^{a}$ Histopathology and Molecular Diagnostics. University Hospital Careggi, Florence, Italy \\ b Section of Pathological Anatomy, Department of Biomedical Sciences and Public Health Polytechnic University of the Marche Region, School of Medicine, \\ United Hospitals, Ancona, Italy \\ ${ }^{c}$ Department of Pathology and Laboratory Medicine, Indiana University School of Medicine, Indianapolis, IN 46202, USA \\ d Anatomic Pathology, Department of Pathology. University of Verona. Verona, Italy \\ e Department of Urology, University Hospital Careggi, Florence, Italy \\ ${ }^{\mathrm{f}}$ Unit of Anatomic Pathology, Department of Surgery, Cordoba University Medical School, Cordoba, Spain, and Champalimaud Clinical Center, Lisbon, \\ Portugal
}

\section{A R T I C L E I N F O}

\section{Article history:}

Received 28 January 2017

Received in revised form 6 March 2017

Accepted 6 March 2017

\section{Keywords:}

Low malignant potential tumors

Multilocular cystic clear cell renal cell

Clear cell papillary renal cell carcinoma

Tubulocystic carcinoma

Small renal tumor

PT1 renal tumor

\begin{abstract}
A B S T R A C T
Introduction: A number of new renal tumor entities have been recognized by the 2016 World Health Organization classification of urologic tumors. The classification includes tumors with different behavior and introduces one tumor with low malignant potential, the multilocular cystic clear cell renal cell neoplasm of low malignant potential (mcCCRCNLMP).

However, some categories still labeled as "carcinoma", such as clear cell papillary renal cell carcinoma (CCPRCC), renal angioleiomyomatous tumor (RAT), and tubulocystic carcinoma (TCRCC), all with a particularly good prognosis when diagnosed as low stage, show no malignant behavior: in fact, no metastases have been reported in these categories when surgically excised. Current experience is limited to supporting these neoplasms as benign entities although, recent literature data is defining these entities as "low malignant potential tumors".

Material and methods: We conducted a search through our files on a consecutive series of 624 renal tumors diagnosed over a period of 2 years to address the incidence of this category of tumors.

Results: Applying strict histological criteria, the "low malignant potential" tumors, comprised $7 \%$ of renal masses that are less than $4 \mathrm{~cm}$ in size and $3.8 \%$ of renal masses measuring $4-7 \mathrm{~cm}$ in the series of 624 renal tumors. When benign tumors are taken into considerations, the benign and "low malignant potential tumors" represent about one third of renal masses $<4 \mathrm{~cm}$ and one sixth of renal masses between 4 and $7 \mathrm{~cm}$. All these cases have not shown recurrence or metastasis at follow-up, mean follow-up of 18 months (range 6-30 months).

Conclusions: This information may assist urologists in developing guidelines for counseling and proper clinical management for patients with "low malignant potential" tumors or small renal masses.
\end{abstract}

(c) 2017 Elsevier GmbH. All rights reserved.

\footnotetext{
* Corresponding author at: Histopathology and Molecular Diagnostics, University Hospital Careggi, Largo Brambilla 3, 50134 Florence, Italy.

E-mail addresses: mariarosaria.raspollini@unifi.it (M.R. Raspollini),

i.montagnani@libero.it (I. Montagnani), r.montironi@univpm.it

(R. Montironi), liang_cheng@yahoo.com (L.Cheng), guidomart@yahoo.com

(G. Martignoni), andreamine@libero.it (A. Minervini),

Sergio.serni@unifi.it(S. Serni),giulio.nicita@unifi.it(G. Nicita),marco.carini@unifi.it

(M. Carini), em1lobea@gmail.com (A. Lopez-Beltran).
}

\section{Introduction}

A number of new renal tumor entities are now recognized by the 2016 World Health Organization (WHO) classification of urologic tumors $[1,2]$.

The classification includes tumors with different behaviors. For example, multilocular cystic renal cell tumor of low malignant potential (mcCCRCNLMP) is now recognized as a non-aggressive tumor compared to the 2004 WHO classification $[3,4]$. 
However, some categories still labeled as “carcinoma”, including clear cell papillary renal cell carcinoma (CCPRCC), renal angioleiomyomatous tumor (RAT), and tubulocystic carcinoma (TCRCC), all with a particularly good prognosis when diagnosed as low stage (pT1a), show no malignant behavior: in fact, no metastases have been reported in these categories when surgically excised [5-14]. RAT is also considered by most authors as a morphologic variation of CCPRCC [15-17].

Because of the recognized good prognosis observed in CCPRCC, renaming them as low malignant tumors has recently been proposed [18].

However, some authorities consider current experience limited to supporting these neoplasms as benign entities. The experience on this tumor ranges from a few cases reported, to about 200 cases, but CCPRCC is recognized as the most common within the low malignant category [19-21].

In order to establish the incidence of these novel categories in clinical practice, we have carried out a 2-year study of a series of 624 consecutive renal tumors treated in a single tertiary center.

\section{Materials and methods}

We searched in the database (code T71000) of Pathology Archives of the University Hospital Careggi, Florence, Italy and identified all kidney tumor cases from September 1, 2013 to September 1, 2015. Exclusion criteria were upper urinary tract urothelial carcinoma, metastasis to the kidney, policystic diseases, simple renal cysts, and biopsies for medical kidney disease. Patient's clinical information was obtained from medical records. The study series included 624 kidney tumors seen in 577 patients. Available hematoxylin-eosin and immunohistochemical slides were re-assessed (MRR and ALB) and final diagnosis was performed in accordance with the 2016 WHO classification of urologic tumors[1]. pT category was assessed according to 2010 revision of TNM [22].

The diagnosis of CCPRCC was made only when the cases were in full accordance with the description of this tumor entity [1]. In all the cases, the diagnosis was not only based on morphological features, but even on immunohistochemical staining such as: CK7 strongly positive, 34 beta E12 and CA IX positive, CD10, RACEMASE negative, as previously reported [23]. The final diagnosis of CCPRCC was not done in the case of borderline morphology [24]; the cases of tumors partially resembling CCPRCC by morphology, with a partially positive CK7 and/or CD10 positivity were classified as low nucleolar grade CCRCC $[1,25]$.

In this series, the most relevant new entities of the 2016 WHO classification compared to the previous classification were CCPRCC, mCCCRCNLMP, RAT, and TCRCC (Fig. 1).

The aim of this research is to identify the incidence of these new entities and considering the benign lesions, estimate the cumulative percentage of small renal masses that have a favorable outcome.

\section{Results}

Out of all cases, $62.7 \%$ of patients were male, most (69.8\%) were treated by conservative kidney surgery; among them, 382 patients underwent conservative surgery for a single mass, and 21 patients underwent conservative surgery for multiple tumors; 174 (30.1\%) patients underwent radical nephrectomy, in 166 cases for a single lesion, and in 8 cases for multiple tumors.

Intrarenal masses less than $4 \mathrm{~cm}$ represented $55.1 \%$ of cases; and the intrarenal mass between 4 and $7 \mathrm{~cm}$ represented 14\% of cases in the current series. Table 1 reports absolute numbers and percentages of kidney tumors according to the present WHO classification.[1]
The series additionally included 51 angiomyolipoma (3 of which of epithelioid subtype, and 4 cases with a leiomyomatous component only), one case of solitary fibrous tumor, one lymphoma, one dendritic cell sarcoma, and one leiomyosarcoma.

Particularly, among the 13 CCPRCC cases analyzed, 8 cases were in male patients, and five in female patients with a mean age of 60.8 years; 12 cases were pT1a stage, with a diameter from 1 to $3.5 \mathrm{~cm}$ (mean $2 \mathrm{~cm}$ ); only one case measured $9 \mathrm{~cm}$ in diameter.

Regarding the 12 mcCCRCNLMP cases analyzed, 8 cases were in male patients, and 4 cases were in female patients, with a mean age of 63 years (range $38-80$ years). The mean diameter was $3 \mathrm{~cm}$ (range $0.8-7 \mathrm{~cm}$ ).

None of the tumors in the "low malignant potential" or benign categories behaved aggressively and none showed recurrence or metastasis at follow-up, mean follow-up of 18 months (range 6-30 months).

\section{Discussion}

In the current series, among the intrarenal masses less than $4 \mathrm{~cm}$, benign tumors and all potentially low malignant tumors (CCPRCC, mCCCRCNLMP, RAT and TCRCC) represent one third of the diagnosis. This leaves $70 \%$ of the pT1a cases as malignant. Among the masses between 4 and $7 \mathrm{~cm}$, benign and low malignant cases account for $17.5 \%$ of the cases, which represent half of the amount compared to the above mentioned masses less than $4 \mathrm{~cm}$ in diameter.

The low malignant potential tumors (CCPRCC, mcCCRCNLMP, RAT, and TCRCC) represent $7 \%$ of the masses less than $4 \mathrm{~cm}$, and they represent $3.7 \%$ of the masses in the category between 4 and $7 \mathrm{~cm}$.

These four types of tumors represent an entity which emerged recently based on novel tumor classification, [1] and on other recent literature data [8,16-18,25-28].

This fact, however, forces urologists to deal with many uncertainties due to limited information and experience currently available on these recently emerged entities [29].

In order to decide what the appropriate follow up scheme should be, this being an increasingly frequent problem in practice, we should clarify if the category still labeled as "carcinoma", such as the case with CCPRCC and TCRCC, [1] is truly made up of renal malignant tumors.

To our knowledge, our study is the first to report on the incidence of these types of tumors diagnosed in the context of the management of patients with intrarenal masses less than $4 \mathrm{~cm}$ diameter and intrarenal masses between 4 and $7 \mathrm{~cm}$. It shows that CCPRCC is the most common subtype seen in this category with a slightly higher incidence (5.4\%) compared to the one reported by Zhou [30] who found a $4.1 \%$ incidence out of 290 nephrectomies performed over a 2-year period.

The different incidence of CCPRCCs among all RCCs that we reported compared to the report of Zhou [30] is probably related to the tumor stage. In our series of cases, when we included all the 458 RCCs, the incidence of CCPRCC represented 2.8\% (with RAT 3\%). When we calculate the incidence of CCPRCCs among the pT1a RCC cases, the incidence represented 5.4\% (with RAT 5.9\%). All tumors are in non end-stage patients.

In our series, the incidence of pT1a CCPRCC tumors was $92.3 \%$ among all the CCPRCCs, this is in accordance with the literature data i.e., according to Diolombi et al., who reported that $91.4 \%$ of the CCPRCCs were pT1 [18].

Importantly, none of our cases, just as the ones in Zhou's series, showed aggressive behavior: in fact, none of the previously reported cases so far has ever recurred or produced metastases 


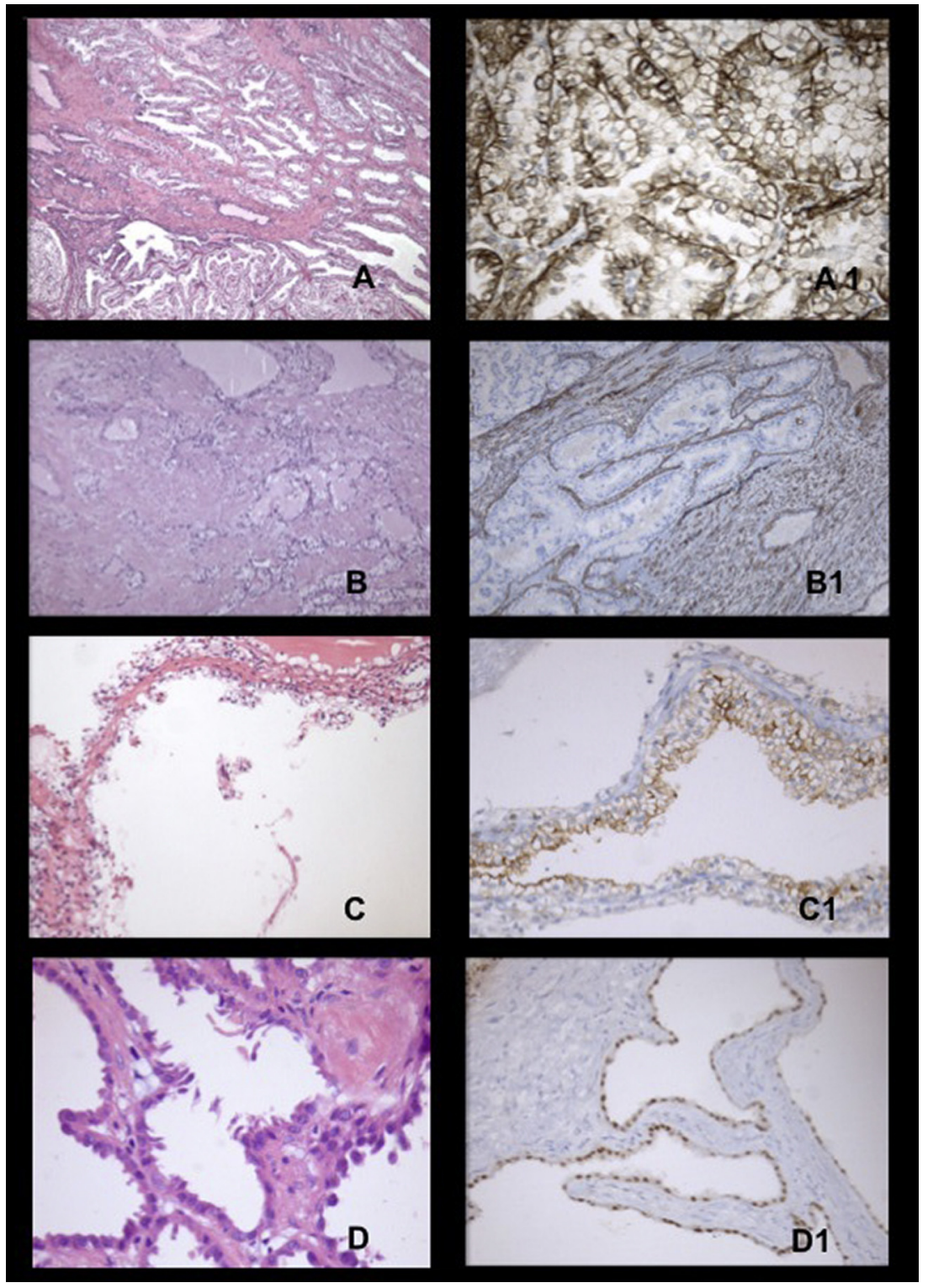

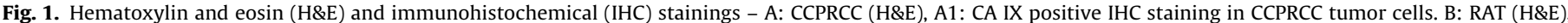

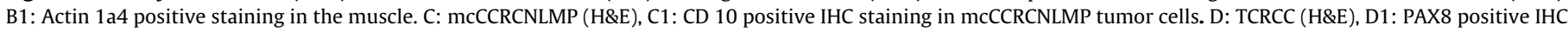
staining in nuclei of TCRCC.

\section{Table 1}

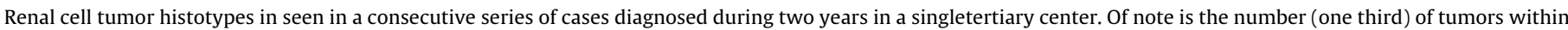
the spectrum of low malignant potential, and the fact that (85\%) had pT1a category.

\begin{tabular}{|c|c|c|c|c|c|}
\hline $\begin{array}{l}\text { Renal tumor } \\
\text { subtype }\end{array}$ & $\begin{array}{l}\text { Mean age (years) } \\
\text { (range) }\end{array}$ & $\begin{array}{l}\text { Gender } \\
(\mathrm{M} ; \mathrm{F})\end{array}$ & $\begin{array}{l}{ }^{\text {a }} \text { No. of renal tumors } \\
\text { (all stages), } N=569\end{array}$ & $\begin{array}{l}\text { Renal mass } \leq 4 \mathrm{~cm}, \\
N=314\end{array}$ & $\begin{array}{l}\text { Renal mass }>4 \leq 7 \mathrm{~cm}, \\
N=80\end{array}$ \\
\hline CCRCC & $63(24-90)$ & $202 \mathrm{M}, 116 \mathrm{~F}$ & 318 & 143 & 43 \\
\hline PRCC & $65.12(46-86)$ & $51 \mathrm{M}, 20 \mathrm{~F}$ & 71 & 44 & 8 \\
\hline Chromophobe RCC & $64.07(38-76)$ & $35 \mathrm{M}, 22 \mathrm{~F}$ & 57 & 31 & 12 \\
\hline unclassified RCC & $67.12(51-80)$ & $4 \mathrm{M}, 4 \mathrm{~F}$ & 8 & 1 & 3 \\
\hline Xp11 traslocation RCC & $54.25(38-76)$ & $3 \mathrm{M}, 1 \mathrm{~F}$ & 4 & 0 & 0 \\
\hline Total malignant & & & 458 & b $219(70 \%)$ & ${ }^{\mathrm{c}} 66(82.5 \%)$ \\
\hline CCPRCC & $60.8(42-74)$ & $8 \mathrm{M}, 5 \mathrm{~F}$ & 13 & 12 & 0 \\
\hline RAT & 54 & $1 \mathrm{~F}$ & 1 & 1 & 0 \\
\hline mcCCRCNLMP & $63(38-80)$ & $8 \mathrm{M}, 4 \mathrm{~F}$ & 12 & 9 & 3 \\
\hline Tubulo cystic RCC & 47 & $1 \mathrm{M}$ & 1 & 1 & 0 \\
\hline Total low malignant & & & 27 & ${ }^{\mathrm{b}} 23(7 \%)$ & $3(3.75 \%)$ \\
\hline Oncocitoma & $66.72(34-90)$ & $38 \mathrm{M}, 34 \mathrm{~F}$ & 72 & 60 & 11 \\
\hline Papillary adenoma & $64(54-86)$ & $7 \mathrm{M}, 5 \mathrm{~F}$ & 12 & 12 & 0 \\
\hline Total benign & & & 84 & $72(23 \%)$ & $11(13.75 \%)$ \\
\hline
\end{tabular}

\footnotetext{
a The series additionally included 55 cases for a total of 624 cases (see Section 3).

b pT1a category.
}

c pT1b category. 
after surgical resection. In addition, no gene mutations have been reported in CCPRCC [28].

Therefore, as long as the surgical approach remains the gold standard, the diagnosis of a low malignant potential tumor after surgery should lead to a less intensive follow up, preferentially based on ultrasound, to reduce cumulative radiation exposure with less utilization of CT scans. It should however be considered that the percentage of benign and "low malignant tumors" in masses between 4 and $7 \mathrm{~cm}$ was half the amount of those less than $4 \mathrm{~cm}$. On the other hand, RAT tumors are viewed by the current WHO classification as a rare variant of CCPRCC with a stroma rich in smooth muscle, and, similar to CCPRCC, none of the reported cases presented aggressive behavior on follow up when diagnosed following strict criteria. In line with this rationale, TCRCC, with about 70 reported cases in literature, should be considered a rare entity; importantly, no malignant behavior has been reported in any pT1 cases [8]. TCRCC associated with malignant behavior were very unusual cases in already advanced disease $(\geq \mathrm{pT} 3)$ or they were associated with papillary RCC or sarcomatoid carcinoma [8,31-32].

We observed that the incidence of mcCCRCNLMP was 3.7\% out of the CCRCC cases, in accordance with the literature [6]. The percentage of mcCCRCNLMP cases with diameter $\leq 4 \mathrm{~cm}$ increases to $6.2 \%$ out of all the pT1a clear cell renal cell carcinoma cases.

Therefore, mcCCRCNLMP represents the second most common subtype with "low malignant potential". In fact due to the available literature, the current WHO classification of renal tumors has renamed this entity as low malignant potential tumor thus recognizing its unique morphology, clinical presentation and molecular characteristics. No gene mutations have been reported unlike clear cell renal cell carcinomas [26]. No case diagnosed following the strict criteria has ever presented malignant behavior [33,34].

Therefore, a renal tumor biopsy which highlights the presence of this type of tumor may be followed by a more conservative approach. However, at the best of our knowledge, at this moment no studies reported the reliability of the needle biopsy in the diagnosis of these new low grade malignant potential tumors.

In conclusion, one third of renal masses less than $4 \mathrm{~cm}$ and one sixth of renal masses between 4 and $7 \mathrm{~cm}$ show benign or low malignant behavior in this large series.

In fact, none of our cases defined as "low malignant potential" have shown aggressive behavior or recurrence in the follow up.

We hope that this data will be confirmed by other large series from tertiary centers, because if this information is properly confirmed, it will assist urologists in developing guidelines for patient counseling and proper clinical management, conforming the follow up scheme and maybe using less invasive diagnostic tools.

\section{References}

[1] H. Moch, P.A. Humphrey, T.M. Ulbright, V.E. Reuter, World Health Organization (WHO) Classification of Tumours of the Urinary System and Male Genital Organs, vol. 8, 4th ed., IARC Press, 2016.

[2] R. Mehra, S.C. Smith, M. Divatia, M.B. Amin, Emerging entities in renal neoplasia, Surg. Pathol. Clin. 8 (2015) 623-656.

[3] J.N. Eble, G. Sauter, J.I. Epstein, I.A. Sesterhenn, World Health Organization (WHO) Classification of Tumours of the Urinary System and Male Genital Organs, vol. 8, third ed., IARC Press, 2004.

[4] T. Li, J. Chen, Y. Jiang, X. Ning, S. Peng, J. Wang, Q. He, X. Yang, K. Gong, Multilocular cystic renal cell neoplasm of low malignant potential: a series of 76 cases, Clin. Genitourin. Cancer. (2016), http://dx.doi.org/10.1016/j.clgc. 2016.03.017, S1558-7673(16)30071-4 (Epub ahead of print).

[5] H. Aydin, L. Chen, L. Cheng, S. Vaziri, H. He, R. Ganapathi, B. Delahunt, C. Magi-Galluzzi, M. Zhou, Clear cell tubulopapillary renal cell carcinoma: a study of 36 distinctive low-grade epithelial tumors of the kidney, Am. J. Surg. Pathol. 34 (2010) 1608-1621, http://dx.doi.org/10.1097/PAS. 0b013e3181f2ee0b.

[6] S. Suzigan, A. López-Beltrán, R. Montironi, R. Drut, A. Romero, T. Hayashi, A.L. Gentili, P.S. Fonseca, I. deTorres, A. Billis, L.C. Japp, E. Bollito, F. Algaba, M.J. Requena-Tapias, Multilocular cystic renal cell carcinoma: a report of 45 cases of kidney tumor of low malignant potential, Am. J. Clin. Pathol. 125 (2006) 217-1621, http://dx.doi.org/10.1309/AH6F-C77P-YR2V-6YAY.
[7] B.A. Alexiev, C. Thomas, Y.S. Zou, Clear cell papillary renal cell carcinoma with angiomyomatous stroma: a histological, immunohistochemical, and fluorescence in situ hybridization study, Virch. Arch. 464 (2014) 709-716, http://dx.doi.org/10.1007/s00428-014-1581-y.

[8] T. Tran, C.L. Jones, S.R. Williamson, J.N. Eble, D.J. Grignon, S. Zhang, M. Wang, L.A. Baldridge, L. Wang, R. Montironi, M. Scarpelli, P.H. Tan, N.B. Simper, E. Comperat, L. Cheng, Tubulocystic renal cell carcinoma is an entity that is immunohistochemically and genetically distinct from papillary renal cell carcinoma, Histopathology 68 (6) (2016) 850-857, http://dx.doi.org/10.1111/ his.12840, May Epub.

[9] B.A. Alexiev, C.B. Drachenberg, Tubulocystic carcinoma of the kidney: a histologic, immunohistochemical, and ultrastructural study, Virch. Arch. 462 (5) (2013) 575-581, http://dx.doi.org/10.1007/s00428-013-1398-0, May; Epub 2013 Mar 24.

[10] M. Michal, O. Hes, J. Nemcova, R. Sima, N. Kuroda, S. Bulimbasic, M. Franco, N. Sakaida, D. Danis, D.V. Kazakov, C. Ohe, M. Hora, Renal angiomyoadenomatous tumor: morphologic, immunohistochemical, and molecular genetic study of a distinct entity, Virch. Arch. 454 (1) (2009) 89-99, http://dx.doi.org/10.1007/s00428-008-0697-3.

[11] M. Michal, O. Hes, F. Havlicek, Benign renal angiomyoadenomatous tumor: a previously unreported renal tumor, Ann. Diagn. Pathol. 4 (5) (2000) 311-315, http://dx.doi.org/10.1053/adpa.2000.17890.

[12] J.H. Park, C. Lee, J.H. Suh, K.C. Moon, Clear cell papillary renal cell carcinoma: a report of 15 cases including three cases of concurrent other-type renal cell carcinomas, Korean J. Pathol. 46 (6) (2012) 541-547, http://dx.doi.org/10 4132/KoreanJPathol.2012.46.6.541, Epub 2012 Dec 26.

[13] J.S. Bhullar, N. Varshney, A.K. Bhullar, V.K. Mittal, A new type of renal cancer-tubulocystic carcinoma of the kidney: a review of the literature, Int. J. Surg. Pathol. 22 (4) (2014) 297-302, http://dx.doi.org/10.1177/ 1066896913509007, Epub 2013 Nov 14.

[14] S.R. Williamson, L. Cheng, Clear cell renal cell tumors: not all that is "clear" is cancer, Urol. Oncol. 34 (7) (2016) 292, http://dx.doi.org/10.1016/j.urolonc. 2016.01.001, Epub 2016 Mar 14.

[15] M. Aron, E. Chang, L. Herrera, O. Hes, M.S. Hirsch, E. Comperat, P. Camparo, P. Rao, M. Picken, M. Michal, R. Montironi, P. Tamboli, F. Monzon, M.B. Amin, Clear cell-papillary renal cell carcinoma of the kidney not associated with end-stage renal disease: clinicopathologic correlation with expanded immunophenotypic and molecular characterization of a large cohort with emphasis on relationship with renal angiomyoadenomatous tumor, Am. J. Surg. Pathol. 39 (7) (2015) 873-888, http://dx.doi.org/10.1097/PAS. 0000000000000446.

[16] S.R. Williamson, L. Cheng, J.N. Eble, L.D. True, N.S. Gupta, M. Wang, S. Zhang, D.J. Grignon, Renal cell carcinoma with angioleiomyoma-like stroma: clinicopathological, immunohistochemical, and molecular features supporting classification as a distinct entity, Mod. Pathol. 28 (2) (2015) 279-294, http://dx.doi.org/10.1038/modpathol.2014.105, Epub 2014 Sep.

[17] F. Petersson, P. Grossmann, M. Hora, M. Sperga, D.P. Montiel, P. Martinek, M.E. Gutierrez, S. Bulimbasic, M. Michal, J. Branzovsky, O. Hes, Renal cell carcinoma with areas mimicking renal angiomyoadenomatous tumor/clear cell papillary renal cell carcinoma, Hum. Pathol. 44 (7) (2013) 1412-1420, http://dx.doi.org/10.1016/j.humpath.2012.11.019, Epub 2013 Feb 21.

[18] M.L. Diolombi, L. Cheng, P. Argani, J.I. Epstein, Do clear cell papillary renal cell carcinoma have malignant potential? Am. J. Surg. Pathol. 39 (12) (2015) 1621-1634, http://dx.doi.org/10.1097/PAS.0000000000000513.

[19] J.R. Srigley, B. Delahunt, J.N. Eble, L. Egevad, J.I. Epstein, D. Grignon, O. Hes, H Moch, R. Montironi, S.K. Tickoo, M. Zhou, P. Argani, The International Society of Urological Pathology (ISUP) Vancouver classification of renal neoplasia, Am. J. Surg. Pathol. 37 (10) (2013) 1469-1489, http://dx.doi.org/10.1097/PAS. 0b013e318299f2d1.

[20] S.K. Tickoo, M.N. dePeralta-Venturina, L.R. Harik, H.D. Worcester, M.E. Salama, A.N. Young, H. Moch, M.B. Amin, Spectrum of epithelial neoplasms in end-stage renal disease. An exprerience from 66 tumor-bearing kidney with emphasis on histologic patterns distinct from those in sporadic adult renal neoplasia, Am. J. Surg. Pathol. 30 (2) (2006) 141-153.

[21] S. Gill, E.C. Kauffman, S. Kandel, S. George, T. Schwaab, B. Xu, Incidence of clear cell papillary renal cell carcinoma in low-grade renal cell carcinoma cases: a 12-year retrospective clinicopathologic study from a single cancer center, Int. J. Surg. Pathol. 24 (3) (2016) 207-212, http://dx.doi.org/10.1177/ 1066896915613432 , Epub 2015 Oct 27.

[22] American Joint Committee on Cancer (AJCC) Staging Manual, Seventh Edition (2010). Published by Springer Science and Business Media.

[23] S. Gobbo, J.N. Eble, D.J. Grignon, G. Martignoni, G.T. MacLennan, R.B. Shah, S. Zhang, M. Brunelli, L. Cheng, Clear cell papillary renal cell carcinoma. A distinct histopathologic and molecular genetic entity, Am. J. Surg. Pathol. 32 (8) (2008) 1239-1245, http://dx.doi.org/10.1097/PAS.0b013e318164bcbb.

[24] S.R. Williamson, N.S. Gupta, J.N. Eble, C.G. Rogers, S. Michalowski, S. Zhang, M. Wang, D.J. Grignon, L. Cheng, Clear cell renal cell carcinoma with borderline features of clear cell papillary renal cell carcinoma combined morphologic, immunohistochemical, and cytogenetic analysis, Am. J. Surg. Pathol. 39 (11) (2015) 1502-1510, http://dx.doi.org/10.1097/PAS.0000000000000514.

[25] H.P. Dhakal, J.K. McKenney, L.Y. Khor, J.P. Reynolds, C. Magi-Galluzzi, C.G. Przybycin, Renal neoplasms with overlapping features of clear cell renal cell carcinoma and clear cell papillary renal cell carcinoma: a clinicopathologic study of 37 cases from a single institution, Am. J. Surg. Pathol. 40 (2) (2016) 141-154, http://dx.doi.org/10.1097/PAS.0000000000000583. 
[26] M.R. Raspollini, F. Castiglione, G. Martignoni, L. Cheng, R. Montironi, A Lopez-Beltran, Unlike in clear cell renal cell carcinoma. KRAS is not mutated in multilocular cystic clear cell renal cell neoplasm of low potential, Virch. Arch. 467 (6) (2015) 687-693, http://dx.doi.org/10.1007/s00428-015-1859-8, Epub 2015 Oct 5.

[27] M.R. Raspollini, F. Castiglione, L. Cheng, R. Montironi, A. Lopez-Beltran, Synchronous clear cell renal cell carcinoma and multilocular cystic renal cell neoplasia of low malignant potential. A clinico-pathologic and molecular study, Pathol. Res. Pract. 212 (5) (2016) 471-474, http://dx.doi.org/10.1016/j. prp.2016.01.001, Epub 2016 Jan 6.

[28] M.R. Raspollini, F. Castiglione, L. Cheng, R. Montironi, A. Lopez-Beltran, Genetic mutations in accordance with a low malignant potential tumor are not demonstrated in clear cell papillary renal cell carcinoma, J. Clin. Pathol. 69 (6) (2016) 547-550, http://dx.doi.org/10.1136/jclinpath-2015-203565, Epub 2016 Mar 3.

[29] U. Capitanio, F. Montorsi, Renal cancer, Lancet 387 (10021) (2016) 894-906, http://dx.doi.org/10.1016/S0140-6736(15)00046-X, Epub 2015 Aug 25.

[30] H. Zhou, S. Zheng, L.D. Truong, J.Y. Ro, A.G. Ayala, S.S. Shen, Clear cell papillary renal cell carcinoma is the fourth most common histologic type of renal cell carcinoma in 290 consecutive nephrectomies for renal cell carcinoma, Hum. Pathol. 45 (1) (2014) 59-64, http://dx.doi.org/10.1016/j.humpath.2013.08. 004, Epub 2013 Oct 31.
[31] T.O. Al-Hussain, L. Cheng, S. Zhang, J.I. Epstein, Tubulocystic carcinoma of the kidney with poorly differentiated foci: a series of 3 cases with fluorescence in situ hybridization analysis, Hum, Pathology 44 (7) (2013) 1406-1411, http://dx.doi.org/10.1016/j.humpath.2012.11.015, Epub 2013 Feb 18.

[32] M. Zhao, X. Teng, G. Ru, Z. Zhao, Q. Hu, L. Han, X. He, Tubulocystic renal cell carcinoma with poorly differentiated foci is indicative of aggressive behavior: clinicopathologic study of two cases and review of the literature, Int. J. Clin. Exp. Pathol. 8 (9) (2015) 11124-11131, eCollection 2015.

[33] S.R. Williamson, S. Hala, J.N. Eble, D.J. Grignon, A. Lopez-Beltran, R. Montironi, P.H. Tan, M. Wang, S. Zhang, G.T. Maclennan, L.A. Baldridge, L. Cheng, Multilocular cystic renal cell carcinoma: similarities and differences in immunoprofile compared with clear cell renal cell carcinoma, Am. J. Surg. Pathol. 36 (10) (2012) 1425-1433, http://dx.doi.org/10.1097/PAS. 0b013e31825b37fo.

[34] S. Halat, J.N. Eble, D.J. Grignon, A. Lopez-Beltran, R. Montironi, P.H. Tan, M Wang, S. Zhang, G.T. MacLennan, L. Cheng, Multilocular cystic renal cell carcinoma is a subtype of clear cell renal cell carcinoma, Mod. Pathol. 23 (7) (2010) 931-936, http://dx.doi.org/10.1038/modpathol.2010.78, Epub 2010 Mar 26. 